\title{
The effect of meal composition on postprandial glucagon-like peptide-1 response in overweight/ obese participants
}

Brian Franklin, Beverley Adams-Huet², Melody Phillips', Joel Mitchell1, Brooke Bouza', Manall Jaffery',

Alex Villanueva', Shane Jenke ${ }^{1}$, Justin Repshas', Leighsa Brace ${ }^{1}$, Henry Aleck', Aaron Caldwell ${ }^{1}$, Elizabeth Sanders ${ }^{1}$, Lyn Dart', Meena Shah ${ }^{1 *}$

From The Twelfth International Society of Sports Nutrition (ISSN) Conference and Expo Austin, TX, USA. 11-13 June 2015

\section{Background}

Glucagon-like peptide-1 (GLP-1) is an incretin hormone secreted in the intestine in response to food intake. GLP-1 may be responsible for nearly $50 \%$ of insulin secretion. Postprandial GLP-1 secretion may be impaired in over- weight/obese $(\mathrm{OW} / \mathrm{O})$ individuals and in patients with type-2 diabetes (T2D). Meals high in protein (HP) or high in monounsaturated fat (HMF) may increase GLP-1 response. However, there are no studies directly comparing HP with HMF meals on postprandial GLP-1 response.

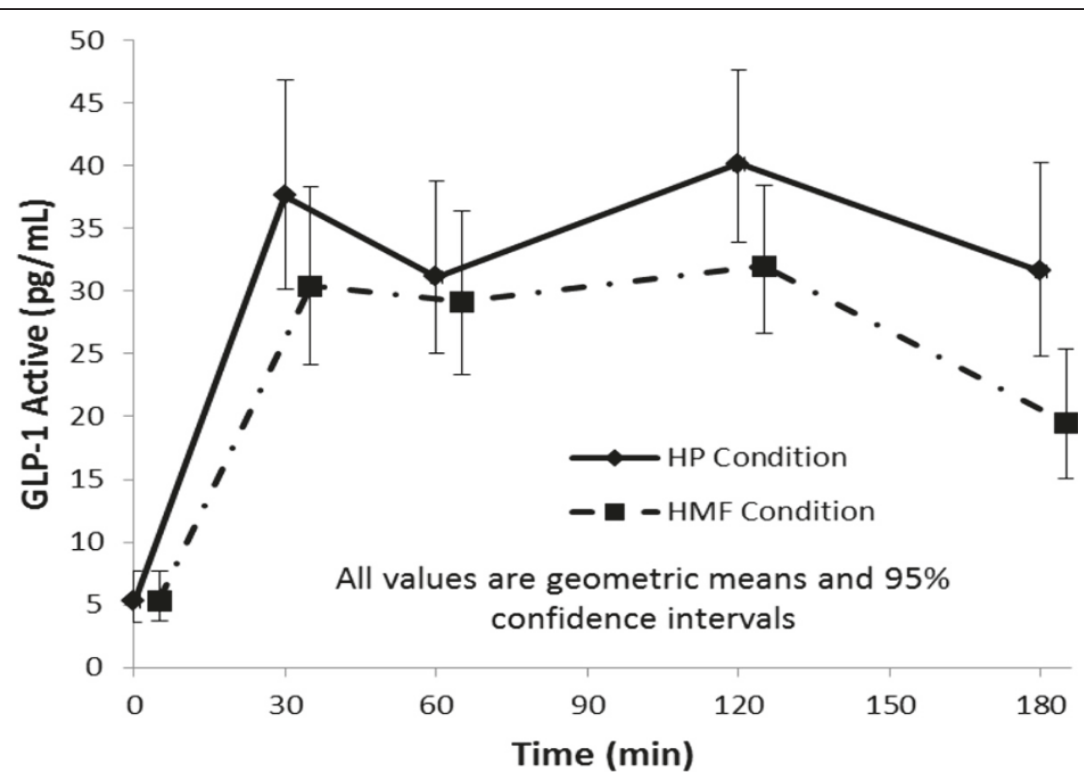

Figure 1

* Correspondence: m.shah@tcu.edu

'Department of Kinesiology, TCU, Fort Worth, TX 76129, USA

Full list of author information is available at the end of the article 


\section{Methods}

Twenty-four OW/O participants (male/female: 12/12; age: $38.7 \pm 15.3$ (mean \pm standard deviation) years; BMI: $31.6 \pm 4.0 \mathrm{~kg} / \mathrm{m}^{2}$ ) were studied. Participants consumed a HMF and a HP meal in a random order at least 4 days apart. The HMF meal contained $35.2 \%$ energy from fat and $20.7 \%$ from monounsaturated fat and the HP meal contained $31.9 \%$ energy from protein. Energy and carbohydrate content were similar across meals. Blood samples were collected in the fasting and postprandial (30, 60,120 , and $180 \mathrm{~min}$ ) states and analyzed for GLP-1 (active and total), insulin, glucagon, $\mathrm{C}$-peptide, and glucose. A mixed effects repeated measures analysis model was used to examine the effect of meal composition on the outcome variables.

\section{Results}

There were statistically significant $(\mathrm{p}<0.01)$ time and time by meal composition interaction effects on active GLP-1 (see figure). Also found were statistically significant $(\mathrm{p}<0.01)$ time, meal composition, and time by meal composition interaction effects on total GLP-1, insulin, C-peptide, and glucagon. The responses were higher on the HP compared to the HMF meal ( $\mathrm{p}<$ 0.05 ) for active and total GLP-1 and C-peptide at 120 and $180 \mathrm{~min}$, insulin at 60,120 , and $180 \mathrm{~min}$, and glucagon at 30,60, 120, and $180 \mathrm{~min}$. There was a significant time $(\mathrm{p}<0.0001)$ but not meal composition $(\mathrm{p}=0.14)$ or time by meal composition interaction $(\mathrm{p}=0.83)$ effect on blood glucose.

\section{Conclusions}

Postprandial GLP-1, insulin, C-peptide, and glucagon responses were higher on the HP compared to the HMF meal but there was no difference in blood glucose response by meal composition. Future studies comparing meal composition on GLP-1 need to be longer in duration and in participants with T2D.

\section{Authors' details}

'Department of Kinesiology, TCU, Fort Worth, TX 76129, USA. ²Department of Clinical Sciences, UT Southwestern Medical Center at Dallas, Dallas, TX 75390, USA. ${ }^{3}$ Department of Nutritional Sciences, TCU, Fort Worth, TX 76129, USA.

Published: 21 September 2015

doi:10.1186/1550-2783-12-S1-P12

Cite this article as: Franklin et al:: The effect of meal composition on postprandial glucagon-like peptide-1 response in overweight/obese participants. Journal of the International Society of Sports Nutrition 201512 (Suppl 1):P12.

\section{Submit your next manuscript to BioMed Central} and take full advantage of:

- Convenient online submission

- Thorough peer review

- No space constraints or color figure charges

- Immediate publication on acceptance

- Inclusion in PubMed, CAS, Scopus and Google Scholar

- Research which is freely available for redistribution

Submit your manuscript at www.biomedcentral.com/submit 